\title{
Optimasi Kapsul Bawang Putih (Allium sativum Linn) sebagai Terapi Alternatif Pengobatan TBC
}

\section{Optimization of Garlic capsule (Allium sativum Linn) for TB Treatment Alternative}

\author{
Novena Yety Lindawati ${ }^{1}$ Hartono $^{2)}$ \\ ${ }^{1,2)}$ Akademi Farmasi Nasional Surakarta \\ 1, 2) Jln. Yos Sudarso 338 surakarta; novena yl@yahoo.com
}

\section{Intisari}

Bawang putih (Allium sativum Linn) terbukti aktif terhadap Mycobacterium tuberculosis. Senyawa alisin yang terkandung dalam bawang putih (Allium sativum Linn) berfungsi sebagai antimikroba spektrum luas yang mampu menghambat bakteri penyebab TBC. Kapsul bawang putih (Allium sativum Linn) harus memenuhi persyaratan sesuai dengan Keputusan Menteri Kesehatan Republik Indonesia No: 661/MENKES/SK/VII/1994 tentang persyaratan obat tradisional.

Hasil penelitian menunjukkan ekstrak bawang putih memiliki khasiat sama dengan bawang puting lanang, pada dosis $240 \mu \mathrm{g} / \mathrm{ml}$ medium (setara dengan $600 \mathrm{mg}$ ekstrak bawang putih per kapsul) memiliki potensi paling besar dalam menghambat pertumbuhan Mycobacterium tuberculosis (diambil dari koloni biakan murni dari kultur sputum pasien yang menderita TBC jenis BTA +2 , kultur positif 9, resisten terhadap rifampisin) dibanding dosis 320 dan $400 \mu \mathrm{g} / \mathrm{ml}$ media. Ekstrak kering bawang putih (Allium sativum Linn) memenuhi persyaratan sebagai bahan isi kapsul obat tradisional, antara lain angka lempeng total 1.5 (dipersyaratkan tidak lebih dari 10); angka kapang dan khamir ekstrak bawang putih $6.10^{2}$ (dipersyaratkan tidak lebih dari $10^{4}$ ); tidak mengandung mikroba patogen (tidak terkontaminasi bakteri coliform, Eschericia coli, Salmonella sp, dan Staphylococcus aureus); tidak terdeteksi adanya aflatoxin (dipersyaratkan tidak lebih dari $30 \mathrm{bpj}$ ); kadar air rata-rata sebesar 1 sampai $2 \%$ (dipersyaratkan tidak lebih dari $10 \%$ ).

Kapsul ekstrak kering bawang putih (Allium sativum Linn) memenuhi persyaratan farmasetika untuk sediaan kapsul obat tradisional hasil uji waktu hancur kurang lebih 13 menit (dipersyaratkan tidak lebih dari 15 menit) dan memenuhi keseragaman bobot yang dipersyaratkan untuk sediaan kapsul.

Kata kunci: TBC, ekstrak kering bawang putih (Allium sativum Linn), parameter kapsul obat tradisional

\begin{abstract}
Garlic (Allium Sativum Linn) proven inhibiting the Mycobacterium tuberculosis propagation. Alisin compound which implied in garlic (Allium Sativum Linn) functioning as wide spectrum antimikroba capable to pursue Tuberkulosis cause by bacterium. Garlic Capsule (Allium Sativum Linn) have to fulfill conditions as according to Decree Of The Minister For Public Health of Republic Indonesia No: 661/MENKES/SK/VII/1994 about traditional medicines.
\end{abstract}


The results shows that garlic extract with $240 \mu \mathrm{g} / \mathrm{ml}$ medium (equivalent by $600 \mathrm{mg}$ garlic extract per capsule) has better potency in pursuing growth of Mycobacterium tuberculosis (taken a from pure breeding colony from patient sputum culture which suffering Tuberkulosis BTA type +2 , positive culture 9, resisten to rifampisin) compared to 320 and $400 \mu \mathrm{g} / \mathrm{ml}$ media.Dry extract of garlic (Allium Sativum Linn) fulfilling conditions upon which fill traditional drug capsule, for example total plate number 1.5 (qualifying at the most 10 ); mould and khamir number $6 \times 10^{2}$ (qualifying at the most $10^{4}$ ); negative result of patogen bacteries such as coliform bacteries, Eschericia Coli, Salmonella Sp, and Staphylococcus aureus; negatife result of of aflatoxin (qualify at the most $30 \mathrm{bpj}$ ); total water content equal to $1-2 \%$ (qualifying at the most $10 \%$ ).

Dry garlic extract (Allium Sativum Linn) capsule fulfilling conditions of pharmaceutical form of traditional capsule result disintegration time less than 13 minute (qualify at the most 15 minute) and fulfill uniformity of weight which qualify for the traditional capsule

\section{Keywords: Tuberkulosis, dry garlic extract (Allium Sativum} Linn), traditional medicines capsule parameter

\section{Pendahuluan}

Penyakit tuberkulosis (TBC) merupakan penyakit yang mudah menular dimana dalam tahun-tahun terakhir memperlihatkan peningkatan dalam jumlah kasus baru maupun jumlah angka kematian yang disebabkan oleh TBC. Hasil Survey Kesehatan Rumah Tangga pada tahun 1995 menunjukan bahwa penyakit TBC merupakan penyebab kematian nomor tiga setelah penyakit kardiovaskuler dan penyakit saluran pernapasan pada semua kelompok umur, dan nomor satu dari golongan penyakit infeksi. TBC belum dapat diberantas, data dari WHO menyatakan Indonesia sebagai negara ketiga didunia dalam hal banyaknya penderita TBC (Anonim, 2007).

Penyakit TBC tidak hanya merupakan persoalan individu tapi sudah merupakan persoalan masyarakat. Kesakitan dan kematian akibat TBC mempunyai konsekuensi yang signifikan terhadap permasalahan ekonomi baik individu, keluarga, masyarakat, perusahaan, dan negara. Beberapa faktor penyebab kegagalan dalam pengobatan penderita TBC antara lain karena pengobatannya menggunakan banyak obat, memakan waktu lama, dan beberapa faktor lain, seperti biaya dan efek samping pengobatan.
Melihat perkembangan dan bahayanya penyakit TBC, peneliti bertujuan untuk mengembangkan bahan alam yang memiliki efek samping yang lebih ringan sebagai alternatif dan terapi pendukung untuk pengobatan. Ada berbagai bahan alam yang dapat digunakan untuk terapi tuberkulosis antara lain; buah mengkudu, rimpang jahe gajah, bunga kembang sepatu, rimpang kunyit, rimpang temu putih, rimpang lempuyang wangi, biji selasih, bawang merah, dan bawang putih. Dalam penelitian ini digunakan bawang putih (Allium sativum Linn) yang terbukti aktif terhadap Mycobacterium tuberculosis. Senyawa alisin yang terkandung dalam bawang putih (Allium sativum Linn) berfungsi sebagai antimikroba spektrum luas yang mampu menghambat bakteri penyebab TBC. Alisin memiliki mekanisme molekuler untuk memblokade aktivitas enzim yang menyebabkan infeksi dan gangguan metabolisme, yakni enzim cysteine proteinase dan enzim alkohol dehidrogenase. Selain itu, kandungan Scordinin (enzim dalam bawang putih yang berfungsi untuk pembentukan tunas) diyakini dapat meningkatkan stamina dan kekebalan tubuh terhadap berbagai jenis penyakit. Hal ini disebabkan kemampuan bawang putih dalam bergabung dengan protein dan menguraikannya, sehingga 
protein tersebut mudah dicerna oleh tubuh (Syamsiah dan Tajudin, 2003).

Bawang putih memiliki aroma yang menyengat sehingga dibutuhkan suatu bentuk sediaan obat seperti kapsul untuk menutup aroma tersebut dan mempermudah bagi pasien penderita TBC untuk mengonsumsinya.

Pembuatan ekstrak kering bawang putih (Allium sativum Linn) sebagai bahan baku kapsul tidak menutup kemungkinan terjadinya pencemaran sehingga perlu dilakukan serangkaian uji untuk mendapatkan kapsul bawang putih (Allium sativum Linn) yang memenuhi persyaratan sesuai dengan Keputusan Menteri Kesehatan Republik Indonesia

No: 661/MENKES/SK/VII/1994 tentang persyaratan obat tradisional meliputi uji kadar air isi kapsul tidak boleh lebih dari $10 \%$, uji angka lempeng total tidak lebih dari 10 , uji angka kapang dan khamir tidak lebih dari $10^{4}$, uji mikroba patogen negatif, dan uji aflatoksin tidak lebih dari 30 bpj. Selain itu sediaan kapsul obat tradisional juga harus memenuhi persyaratan meliputi uji waktu hancur kurang dari 15 menit, uji keseragaman bobot kapsul.

Pembuatan kapsul bawang putih (Allium sativum Linn) yang poten terhadap Mycobacterium tuberculosis dan memenuhi persyaratan obat tradisional yang berbentuk kapsul bisa digunakan sebagai terapi alternatif pengobatan TBC.

\section{Metode Penelitian}

Bahan yang digunakan dalam penelitian ini adalah bawang putih (Allium sativum Linn) yang kulitnya berwarna putih keunguan yang diperoleh dari pasar jongke, Pajang, Surakarta. Bawang putih tersebut dibuat menjadi ekstrak kering sebagai isi kapsul.

\section{A. Cara Kerja}

1. Pembuatan ekstrak kering bawang putih (Allium sativum Linn)

Sepuluh kilo bawang putih (Allium sativum Linn) dikupas kulit luarnya dan diiris kecil-kecil, dicampur dengan air 2 kali lipatnya, dihaluskan dengan blender selanjutnya disentrifus dengan kecepatan $3000 \mathrm{rpm}$ selama 15 menit. Supernatan yang diperoleh kemudian diuapkan dengan evaporator hingga kental, penguapan dilanjutkan di oven pada suhu $50{ }^{\circ} \mathrm{C}$ sampai didapatkan ekstrak kering bawang putih (Allium sativum Linn) yang memenuhi bobot konstan menurut Farmakope Indonesia edisi III (1979).

2. Uji potensi antibakteri ektrak kering bawang putih (Allium sativum Linn) terhadap Mycobacterium tuberculosis dengan metode dilusi padat.

a. Pembuatan inokulum Mycobacterium tuberculosis: diambil koloni biakan murni dari kultur sputum pasien yang menderita TBC jenis BTA +2, kultur positif 9, resisten terhadap rifampisin kemudian diencerkan dengan larutan $\mathrm{NaOH} 4 \%$ dalam perbandingan (1:2)

b. Pengujian dan penentuan potensi ekstrak kering bawang putih: disiapkan 8 media Lowenstein Jensen (LJ) yang tidak mengandung larutan ekstrak kering bawang putih ataupun rifampisin sebagai kontrol negatif, 8 media LJ yang mengandung rifampisin $40 \mu \mathrm{g} / \mathrm{ml}$ medium yang mewakili $100 \mathrm{mg} / \mathrm{kapsul}, 8$ media LJ yang mengandung larutan ekstrak kering bawang putih $240 \mu \mathrm{g} / \mathrm{ml}$ medium, 8 media LJ yang mengandung larutan ekstrak kering bawang putih $320 \mu \mathrm{g} / \mathrm{ml}$ medium, dan 8 media LJ yang mengandung larutan ekstrak kering bawang putih $400 \mu \mathrm{g} / \mathrm{ml}$ medium. Sebelum dilakukan inokulasi, semua media LJ tersebut diuji terlebih dahulu dengan menginkubasi media pada suhu $37^{\circ} \mathrm{C}$ selama 1 minggu untuk melihat kemungkinan terjadinya kontaminasi. Setelah media LJ tidak mengalami kontaminasi, selanjutnya diinokulasikan 1 apusan dengan kapas lidi steril larutan bakteri. Inkubasi dilakukan selama 4-6 minggu pada suhu $37^{\circ} \mathrm{C}$. Setelah 4-6 minggu, diamati pertumbuhan bakteri tersebut pada masing-masing media.

3. Pengujian terhadap ekstrak kering bawang putih (Allium sativum Linn) sebagai isi kapsul.

a. Uji angka lempeng total ekstrak kering bawang putih: disiapkan 5 tabung atau lebih yang masing-masing telah diisi dengan $9 \mathrm{ml}$ pengecer $\mathrm{NaCl} 0,9$ $\%$. Dari hasil homogenasi pada penyiapan ekstrak kering bawang putih dipipet 
pengeceran $10^{-1}$ sebanyak $1 \mathrm{ml}$ ke dalam tabung yang berisi pengencer $\mathrm{NaCl} 0,9 \%$ pertama hingga diperoleh pengenceran 102 dan dikocok hingga homogen. Dibuat pengenceran selanjutnya hingga $10^{-6}$ atau sesuai dengan yang diperlukan. Dari setiap pengenceran dipipet $1 \mathrm{ml}$ ke dalam cawan petri dan dibuat duplo. Ke dalam tiap cawan petri dituangkan $15-20 \mathrm{ml}$ media PCA (Plate Count Agar) (45 \pm 10$)$. Segera cawan petri digoyang dan diputar sedemikian rupa hingga suspensi terbesar merata. Untuk mengetahui sterilitas media dan pengencer dibuat uji kontrol (blangko). Pada satu cawan hanya diisi 1 $\mathrm{ml}$ pengencer dan media agar, dan pada cawan yang lain diisi pengencer dan media. Setelah media memadat, cawan petri diinkubasi pada suhu $35-37{ }^{\circ} \mathrm{C}$ selama 24-48 jam dengan posisi terbalik, jumlah koloni yang tumbuh diamati dan dihitung (Anonim, 1998; Hafid dan Kusumawati, 2001).

b. Uji angka kapang dan khamir ekstrak kering bawang putih: disiapkan 3 buah tabung yang masing-masing diisi $9 \mathrm{ml}$ ASA (Air Suling Agar). Dari hasil homogenisasi pada penyiapan ekstrak kering bawang putih dipipet $1,0 \mathrm{ml}$ pengenceran $10^{-1}$ ke dalam tabung ASA pertama hingga diperoleh pengenceran $10^{-}$ 2 dan dikocok sampai homogen. Dibuat pengenceran selanjutnya hingga $10^{-4}$. Dari masing-masing pengenceran dipipet 1,0 $\mathrm{ml}$, dituangkan pada permukaan PDA (Potato Dextrose Agar), segera digoyang sambil diputar agar suspensi terbesar merata dan dibuat duplo. Untuk mengetahui sterilitas media dan pengencer dilakukan uji blangko. Ke dalam satu cawan petri dituangkan media dan dibiarkan memadat, ke dalam cawan petri lainnya dituangkan media dan pengencer, kemudian dibiarkan memadat. Seluruh cawan petri diinkubasi pada suhu 20-25 ${ }^{\circ} \mathrm{C}$ selama 5-7 hari. Sesudah 5 hari inkubasi, dicatat jumlah koloni jamur yang tumbuh, pengamatan terakhir pada inkubasi 7 hari. Koloni ragi dibedakan karena bentuknya bulat kecil-kecil putih hampir menyerupai bakteri. Lempeng agar yang diamati adalah lempeng yang terdapat 40-60 koloni jamur (Anonim, 1998; Hafid dan Kusumawati, 2001). c. Uji mikroba patogen ekstrak kering bawang putih: uji nilai duga terdekat (MPN) Coliform: Disiapkan 5 tabung atau lebih yang masing-masing telah diisi dengan $9 \mathrm{ml}$ pengencer $\mathrm{NaCl} 0,9 \%$ hasil homogenisasi pada penyiapan ekstrak kering bawang putih dipipet pengenceran $10^{-1}$ sebanyak $1 \mathrm{ml}$ ke dalam tabung yang berisi pengencer $\mathrm{NaCl} \quad 0,9 \%$ pertama hingga diperoleh pengenceran $10^{-2}$ dan dikocok hingga homogen. Dibuat pengenceran selanjutnya hingga $10^{-6}$ atau sesuai dengan yang diperlukan (Anonim, 1997; Hafid dan Kusumawati, 2001).

1) Uji Escherichia coli: dipilih biakan positif pada uji MPN Coliform, $1 \mathrm{ml}$ dari masing-masing biakan tersebut diinokulasikan ke dalam MBC (Mac Conkey Broth) dan diinkubasi pada suhu $37{ }^{\circ} \mathrm{C}$ selama 24-48 jam. Terbentuknya gas dalam tabung Durham menunjukkan fekal Coliform positif, kemudian biakan digoreskan pada media BGLB (Briliant Green Lactose Bile Broth). Diinkubasi pada suhu $37{ }^{\circ} \mathrm{C}$ selama 24 jam. Dipilih koloni hijau dengan kilap logam dan bintik biru kehijauan ditengahnya dari BGLB, digoreskan pada NA (Nutrien Agar) miring dan diinkubasikan pada suhu $37{ }^{\circ} \mathrm{C}$ selama 24 jam. Dilakukan pewarnaan Gram Escherichia coli merupakan bakteri gram negatif bentuk batang agak membulat. Dilanjutkan dengan penetapan IMVIC sebagai berikut. Uji Indol, Uji Metil merah, uji Voges-Proskauer dan Uji Citrate (Anonim, 1997; Hafid dan Kusumawati, 2001).

2) Uji Salmonella: Cuplikan dalam LB (Lactose Broth) dengan hasil homogenisasi ekstrak kering bawang putih diinkubasi pada suhu $37{ }^{\circ} \mathrm{C}$ selama 18-24 jam. Dipipet masingmasing ml biakan LB ke dalam $50 \mathrm{ml}$ media TBGB (Tetrathionate Brilliant Green Broth) dan $50 \mathrm{ml} \mathrm{SCB}$ (Selenit Cysteine Broth) dan diinkubasi pada suhu $43{ }^{\circ} \mathrm{C}$ selama 24 jam. Dari masing-masing biakan TBGB dan SCB diinokulasikan 1 sengkelit pada permukaan BGA (Brilliant Green Agar) dan BSA (Bismuth Sulfit Agar) dan diinkubasikan pada suhu $37{ }^{\circ} \mathrm{C}$ 
selama 24 jam. Koloni yang tumbuh diamati dan diindentifikasikan dan kemudian dilakukan uji serologi (Anonim, 1997; Hafid dan Kusumawati, 2001).

3) Uji Staphylococcus aureus: Disiapkan 3 buah tabung yang masing-masing telah diisi dengan $9 \mathrm{ml}$ BPW (Blood Pepton Water). Dari hasil homogenisasi pada penyiapan ekstrak kering bawang putih $10^{-1}$ sebayak $1 \mathrm{ml}$ ke dalam tabung reaksi berisi $9 \mathrm{ml}$ BPW hingga diperoleh pengenceran $10^{-2}$, dikocok. Dipipet $1 \mathrm{ml}$ ke dalam tabung reaksi berisi $9 \mathrm{ml}$ BPW hingga diperoleh pengenceran $10^{-3}$. Dari masing-masing pengenceran dipipet 0,25 ml, dituangkan pada permukaan BP (Blood Plate) agar, disebar ratakan menggunakan batang kelas bengkok dan dibuat duplo. Dibiarkan beberapa saat hingga inokulum terserap dalam media. Diinkubasi pada suhu $37{ }^{\circ} \mathrm{C}$ selama 24-48 jam dengan posisi cawan dibalik. Setelah 24 jam dipilih cawan dengan jumlah 30-300 koloni berwarna hitam mengkilap dan dikelilingi daerah jernih. Posisi koloni diberi tanda dan diinkubasi dilanjutkan hingga 48 jam. Seluruh koloni yang tumbuh selama periode inkubasi dihitung kemudian dilakukan uji koagulase (Anonim, 1997; Hafid dan Kusumawati, 2001).

d. Uji aflatoksin ekstrak kering bawang putih: Timbang seksama sejumlah sampel serbuk bawang putih, ekstraksi menggunakan $2 \mathrm{ml}$ kloroform dengan cara di vortex, kemudian disaring. Filtrat pertama disisihkan, residu diekstraksi dua kali kembali dengan $2 \mathrm{ml}$ kloroform menggunakan vortex, disaring sehingga diperoleh filtrat 2 dan filtrat 3. Gabungan filtrat 1,2, dan 3 dievaporasikan sampai terbentuk ekstrak kental. Larutkan ekstrak kental yang diperoleh dengan kloroform sampai volume $50 \mu l$. Totolkan $5 \mu$ l larutan sampel pada lempeng silika gel GF 254 kemudian eluasi dengan fase gerak Kloroform-metanol 98:2 dengan baku pembanding Aflatoxin B1. Amati Rf dari sampel dan baku standar aflatoxin B1 (Lembar kerja Uji Kimia LPPT-UGM, 2008). e. Uji kadar air ektrak kering bawang putih : Penetapan kadar air dilakukan dengan cara destilasi, 5 gram bahan uji didestilasi dengan $200 \mathrm{ml}$ toluen. Kadar air dalam \% dan penetapan kadar air dilakukan secara duplo untuk setiap pengamatan. (Anonim, 1979; Hafid dan Kusumawati, 2001).

4. Pembuatan kapsul bawang putih (Allium sativum Linn)

Dari hasil uji potensi antibakteri ekstrak kering bawang putih terhadap Mycobacterium tuberculosis, ekstrak yang paling aktif (poten) dimasukkan ke dalam cangkang kapsul yang sesuai.

5. Pengujian terhadap kapsul bawang putih (Allium sativum Linn)

a. Uji waktu hancur kapsul bawang putih: uji waktu hancur yang dilakukan terhadap kapsul sama dengan uji waktu hancur tablet menurut Farmakope Indonesia edisi III (1979). Pengujian waktu hancur dilakukan secara duplo untuk setiap pengamatan.

b. Uji keseragaman bobot kapsul bawang putih: uji keseragaman bobot kapsul dilakukan terhadap kapsul sama dengan uji waktu hancur tablet menurut Farmakope Indonesia edisi III (1979). Uji dilakukan secara duplo.

\section{B. Teknik dan Analisis Hasil}

Banyaknya pertumbuhan Mycobacterium tuberculosis dalam media yang telah mengandung ekstrak kering bawang putih (Allium sativum Linn) yang mewakili dosis 600 $\mathrm{mg}, 800 \mathrm{mg}$, dan $1000 \mathrm{mg}$ dalam tiap kapsul memperlihatkan potensi daya antimikroba ekstrak tersebut. Pertumbuhan Mycobacterium tuberculosis dibaca dengan cara sebagai berikut: negatif bila tidak ada pertumbuhan, disebutkan jumlah koloninya bila 1-5, positif 6 bila jumlah koloni 6-25, positif 7 bila jumlah koloni 26-100, positif 8 bila jumlah koloni $>100$, positif 9 bila pertumbuhan koloni menutupi seluruh permukaan medium. Cara menentukan Mycobacterium tuberculosis resisten atau sensitif terhadap media LJ yang mengandung ekstrak kering bawang putih (Allium sativum Linn): sensitif bila tidak ada pertumbuhan dan atau ada pertumbuhan dengan selisih $>1$ dengan medium kontrol dan resisten bila ada 
pertumbuhan $=$ kontrol dan atau pertumbuhan selisih satu dengankontrol.

\section{Hasil dan Pembahasan \\ A. Pembuatan Ekstrak Kering bawang putih}

Pada penelitian ini simplisia yang dipilih adalah bawang putih dengan kulit berwarna putih keunguan diperoleh dari pasar jongke, Pajang, Surakarta. Bawang putih yang dipilih adalah bawang putih dengan kulit berwarna putih keunguan karena dinyatakan bahwa jenis ini memiliki potensi sebagai daya anti mikroba terhadap Mycobacterium tuberculosis (Syamsiah dan Tajudin, 2003).

Dalam pembuatan ekstrak kering bawang putih digunakan sepuluh kilo bawang putih yang telah dikupas kulit luarnya dan diiris kecil-kecil, dicampur dengan air sebanyak 2 kali lipat berat bawang putih, dihaluskan dengan blender. Hasil penghalusan dengan blender disaring dengan penyaring kasa terlebih dahulu untuk selanjutnya disentrifus dengan kecepatan $3000 \mathrm{rpm}$ selama 15 menit sehingga bisa dipisahkan supernatan dari ampasnya. Supernatan yang diperoleh sebanyak 10.000 $\mathrm{ml}$, dipisahkan, kemudian diuapkan dengan evaporator hingga kental. Ekstrak kental bawang putih selanjutnya dikeringkan menggunakan oven pada suhu $50{ }^{\circ} \mathrm{C}$ sampai didapatkan ekstrak kering bawang putih sampai diperoleh bobot konstan. Diperoleh ekstrak kering bawang putih sebesar 740 gram (rendemen 7,4\% b/b dari bawang basah). Suhu penguapan ekstrak basah ditetapkan $50{ }^{\circ} \mathrm{C}$ dimaksudkan untuk menghindari kerusakan kandungan kimia dari bawang putih.

Ekstrak kering yang diperoleh berupa bongkahan kasar, berukuran besar (menggumpal menjadi seperti kerikil kecil), berwarna kuning kecoklatan dengan bau khas bawang putih. Karena bentuknya yang besar dan tidak seragam, maka dilakukan pengecilan ukuran partikel menggunakan mortir dan stamper sehingga diperoleh ekstrak kering bawang putih dalam bentuk serbuk halus.

\section{B. Uji potensi antibakteri ektrak kering bawang putih (Allium sativum Linn) terhadapMycobacterium tuberculosis dengan metode dilusi padat.}

Uji potensi antibakteri ekstrak kering bawang putih dilakukan terhadap Mycobacterium tuberculosis yang diperoleh dari koloni biakan murni dari kultur sputum pasien yang menderita TBC jenis BTA +2, kultur positif 9. Diperoleh hasil sebagai berikut:

Tabel 1. Uji potensi antibakteri ekstrak kering bawang putih terhadap Mycobacterium tuberculosis

\begin{tabular}{|c|c|c|c|c|c|}
\hline \multirow[t]{2}{*}{ Replikasi } & \multicolumn{3}{|c|}{$\begin{array}{c}\text { Kadar Ekstrak bawang putih } \\
(\mu \mathrm{g} / \mathrm{ml} \text { medium })\end{array}$} & \multirow{2}{*}{$\begin{array}{c}\text { Kontrol } \\
\text { negatif }\end{array}$} & \multirow{2}{*}{$\begin{array}{c}\begin{array}{c}\text { Rifampisin } \\
(\mu \mathrm{g} / \mathrm{ml} \text { medium })\end{array} \\
\mathbf{4 0} \\
\end{array}$} \\
\hline & 240 & 320 & 400 & & \\
\hline 1. & - & +9 & +6 & +9 & +8 \\
\hline 2. & +7 & - & +8 & +8 & +8 \\
\hline 3. & - & +7 & +9 & +8 & +9 \\
\hline 4. & - & +6 & +6 & +9 & +9 \\
\hline 5. & - & +9 & +8 & +9 & +9 \\
\hline 6. & - & - & +7 & +7 & +9 \\
\hline 7. & - & - & +7 & +8 & +9 \\
\hline 8. & - & +8 & +8 & +9 & +8 \\
\hline
\end{tabular}

Dari hasil uji potensi antibakteri ekstrak kering bawang putih terhadap Mycobacterium tuberculosis diketahui bahwa ektrak bawang putih dengan dosis $240 \mu \mathrm{g} /$ $\mathrm{ml}$ medium (setara dengan $600 \mathrm{mg}$ ekstrak bawang putih per kapsul) memiliki potensi menghambat pertumbuhan Mycobacterium tuberculosis, bahkan lebih sensitif daripada rifampisin 40 $\mu \mathrm{g} / \mathrm{ml}$ medium (setara dengan $100 \mathrm{mg}$ rifampisin per kapsul). Dari 8 plate replikasi uji potensi anti bakteri, hanya 1 plate yang mengalami pertumbuhan 26 - 100 koloni, dan diduga hal tersebut terjadi karena buman error.

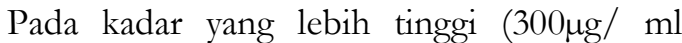
media dan $400 \mu \mathrm{g} / \mathrm{ml}$ media) justru tidak 
sensitif terhadap Mycobacterium tuberculosis, semakin tinggi kadarnya justru semakin resisten, diduga terdapat senyawa lain yang ikut larut di dalam eksrak yang justru menjadi mendukung perkembangbiakan bakteri Mycobacterium tuberculosis. Perlu dilakukan penelitian lebih lanjut untuk mengisolasi senyawa aktif dari bawang putih yang berperan sebagai anti tubercolusis karena pada penelitian ini, baru sampai tahap awal yakni mengambil fase larut air dari bawang putih, dimana dimungkinkan masih sangat banyak bahan non aktif yang ikut tersari dan tercampur dalam ekstrak yang dihasilkan. Dari uji ini, ditetapkan kadar ekstrak kering bawang putih yang paling poten sebagai anti Mycobacterium tuberculosis adalah $240 \mu \mathrm{g} / \mathrm{ml}$ medium, atau setara dengan $600 \mathrm{mg}$ ekstrak kering bawang putih per kapsul.

C. Pengujian terhadap ekstrak kering bawang putih (Allium sativum Linn) sebagai isi kapsul.

1. Uji angka lempeng total ekstrak kering bawang putih (Allium sativum Linn)

Penetapan angka lempeng total dilakukan dengan metode dilusi dengan menggunakan media agar dan pengencer $\mathrm{NaCl} 0,9 \%$. Setelah media memadat, cawan petri diikubasi pada suhu $35-37$ ${ }^{0} \mathrm{C}$ selama 24-48 jam dengan posisi terbalik. Jumlah koloni yang tumbuh sebagai berikut:

Tabel 2. Angka lempeng total ekstrak kering bawang putih (Allium sativum Linn)

\begin{tabular}{ccc}
\hline Replikasi & Angka Lempeng Total & Persyaratan \\
\hline 1. & 2 & 10 \\
2. & 1 & 10 \\
\hline
\end{tabular}

Hasil pengujian angka lempeng total menunjukkan bahwa ekstrak bawang putih kering yang dihasilkan memenuhi persyaratan angka lempeng total isi kapsul obat tradisional tidak lebih dari 10.

2. Uji angka kapang dan khamir ekstrak kering bawang putih (Allium sativum Linn)

Penetapan angka kapang dan khamir dilakukan dengan menggunakan metode dilusi dengan pengencer $\mathrm{NaCl} 0,9 \%$ dengan media agar pada cawan petri. Seluruh cawan petri diinkubasi pada suhu 20-25 ${ }^{\circ} \mathrm{C}$ selama 5-7 hari. Sesudah 5 hari inkubasi, dicatat jumlah koloni jamur yang tumbuh, pengamatan terakhir pada inkubasi 7 hari. Koloni ragi dibedakan karena bentuknya bulat kecil-kecil putih hampir menyerupai bakteri. Lempeng agar yang diamati dan didapatkan hasil sebagai berikut:

Tabel 3. Angka kapang dan khamir ekstrak kering bawang putih (Allium sativum Linn)

\begin{tabular}{ccc}
\hline Replikasi & Angka kapang dan khamir & Persyaratan \\
\hline 1. & $6.10^{2}$ & $10^{4}$ \\
2. & $6.10^{2}$ & $10^{4}$ \\
\hline
\end{tabular}

Hasil pengujian angka kapang dan khamir dari ekstrak kering bawang putih memenuhi persyaratan angka kapang dan khamir isi kapsul obat tradisional yakni tidak lebih dari $10^{4}$.

3. Uji mikroba patogen ekstrak kering bawang putih (Allium sativum Linn)
1) Uji nilai duga terdekat (MPN) Coliform

Penetapan MPN Coliform menggunakan metode dilusi dengan menggunakan pengencer $\mathrm{NaCl} 0,9 \%$ dengan menggunakan tabung Durham. Pada uji ini juga dibuat seri pengenceran untuk uji perkiraan dan uji konfirmasi. 
Seluruh tabung diikubasi pada suhu 37 ${ }^{\circ} \mathrm{C}$ selama 24-48 jam. Kemudian dilakukan pengamatan terhadap pembentukan gas. Jumlah tabung yang positif gas dicatat dan hasil pengamatan tersebut dirujuk pada tabel Nilai Duga Terdekat (NDT) atau Minimal Presumtif Number (MPN). Angka yang diperoleh dari tabel menyatakan jumlah bakteri coliform dalam tiap-tiap gram contoh yang diuji. Hasil yang diperoleh nilai MPN Coliform ekstrak kering bawang putih dari replikasi duplo adalah 0 atau tidak terdeteksi, ini membuktikan bahwa dalam ekstrak kering bawang putih yang dihasilkan tidak mengandung bakteri coliform.

2) Uji Escherichia coli.

Penetapan adanya Escherichia coli merupakan lanjutan dari uji MPN Coliform. Kemudian dilakukan pewarnaan Gram. Escherichia coli yang merupakan bakteri gram negatif bentuk batang agak membulat. Setelah itu dilanjutkan dengan penetapan IMVIC sebagai berikut: Uji Indol, Uji Methil merah, Uji Voges-Proskauer dan Uji Citrate. Hasil yang diperoleh dalam ekstrak kering bawang putih adalah tidak terdeteksi adanya Escherichia coli.

3) Uji Salmonella

Penetapan adanya Salmonella dilakukan dengan pembiakan cuplikan LB (Lactose Broth) pada media TBGB (Tetrathionate Brilliant Green Broth) dan SCB (Selenit Cysteine Broth) kemudian diinkubasikan pada permukaan BGA (Brilliant Green Agar) dan BSA (Bismuth Sulfit Agar) dan diinkubasikan pada suhu $37^{\circ} \mathrm{C}$ selama 24 jam. Koloni yang tumbuh diamati dan diidentifikasi dan kemudian dilakukan uji serologi. Hasil yang diperoleh dalam ekstrak kering bawang putih adalah tidak terdeteksi adanya Salmonella.

4) Uji Staphylococcus aureus.

Penetapan adanya Staphylococcus aureus dilakukan dengan metode dilusi dengan pengencer BPW (Blood Pepton Water) yang kemudian dituangkan pada media
BP agar. Setelah dibiarkan beberapa saat hingga inokulum terserap dalam media kemudian inkubasi pada suhu $37{ }^{\circ} \mathrm{C}$ selama 24-48 jam dengan posisi cawan dibalik. Setelah 24 jam dipilih cawan dengan jumlah 30-300 koloni berwarna hitam mengkilap dan dikelilingi daerah jernih. Posisi koloni diberi tanda dan inkubasi dilanjutkan hingga 48 jam. Seluruh koloni yang tumbuh selama periode inkubasi dihitung kemudian dilakukan uji koagulase. Hasil yang diperoleh dalam ekstrak kering bawang putih adalah tidak terdeteksi adanya Staphylococcus aureus serta Staphylococcus epidermis. Ekstrak kering bawang putih yang digunakan sebagai bahan isi kapsul telah memenuhi persyaratan yaitu tidak mengandung mikroba patogen dalam isi kapsul obat tradisional (hasil uji mikroba patogen negatif).

4. Uji aflatoksin ekstrak kering bawang putih (Allium sativum Linn)

Dalam penetapan adanya cemaran aflatoxin yang dilakukan dengan metode KLT. Hasil uji (terlampir) yang diperoleh dalam ekstrak kering bawang putih tidak terdeteksi adanya aflatoxin sehingga memenuhi persyaratan jumlah aflatoksin isi kapsul obat tradisional tidak lebih dari $30 \mathrm{bpj}$.

5. Uji kadar air ekstrak kering bawang putih (Allium sativum Linn)

Penetapan kadar air dilakukan dengan cara destilasi. Prinsip dari metode ini terletak dalam destilasi dengan bahan yang pelarut menguap yang tidak dapat bercampur dengan air, seperti toluen. Pada saat proses destilasi toluen yang menguap sebagai campuran azeotrop dengan air, akan pada pendingingan akan terpisah kembali, sehingga jumlah air yang terdestilasi terlihat dan dapat dicatat volumenya (Voight, 1994).

Kadar air ekstrak kering bawang putih sebesar 1-2 \%, nilai ini masih memenuhi persyaratan kadar air untuk isi kapsul obat tradisional tidak lebih dari 10\%. 
Tabel 4. Kadar air ekstrak kering bawang putih (Allium sativum Linn) dengan metode destilasi

\begin{tabular}{ccc}
\hline Replikasi & Volume air & $\begin{array}{c}\text { Kadar air ekstrak kering } \\
\text { bawang putih }\end{array}$ \\
\hline 1. & $0,1 \mathrm{ml}$ & $2 \%$ \\
2. & $0,05 \mathrm{ml}$ & $1 \%$ \\
\hline
\end{tabular}

\section{Pembuatan dan Pengujian kapsul ekstrak kering bawang putih (Allium sativum Linn) \\ Penelitian ini memperlihatkan}

Mycobacterium tuberculosis uji yang digunakan bersifat sensitif terhadap ekstrak kering bawang putih dengan kadar $240 \mu \mathrm{g} / \mathrm{ml}$ medium. Kadar tersebut mewakili sediaan kapsul yang berisi $600 \mathrm{mg}$ ekstrak kering bawang putih tiap kapsul. Sediaan kapsul ekstrak bawang putih yang dibuat adalah 600 mg tiap kapsul dengan alat pengisi kapsul sederhana. Bahan kapsul yang digunakan jenis kapsul keras, terbuat dari gelatin dengan ukuran kapsul O. Pengujian terhadap sediaan kapsul obat tradisional meliputi uji keseragaman bobot dan waktu hancur.

1. Uji waktu hancur kapsul bawang putih (Allium sativum Linn) $600 \mathrm{mg}$.

Uji waktu hancur yang dilakukan terhadap kapsul sama dengan uji waktu hancur tablet menurut Farmakope Indonesia edisi III (1979). Hasil uji waktu hancur kapsul bawang putih $600 \mathrm{mg}$ sebagai berikut:

Tabel 5. Uji waktu hancur kapsul bawang putih (Allium sativum Linn) $600 \mathrm{mg}$

\begin{tabular}{ccc}
\hline Replikasi & $\begin{array}{c}\text { Waktu hancur kapsul } \\
\text { bawang putih 600 mg }\end{array}$ & Persyaratan \\
\hline 1. & 12 menit 47 detik & Kurang dari 15 menit \\
2. & 13 menit 08 detik & Kurang dari 15 menit \\
\hline
\end{tabular}

Hasil uji waktu hancur kapsul bawang putih $600 \mathrm{mg}$ memenuhi persyaratan uji waktu hancur jika waktu yang diperlukan untuk menghancurkan kelima kapsul tersebut tidak lebih dari 15 menit .Uji waktu hancur ini menggambarkan berapa lama kapsul hancur setelah diminum sehingga bisa segera diabsorbsi di dalam tubuh yang mengonsumsi.
2. Uji keseragaman bobot kapsul bawang putih (Allium sativum Linn)

Keseragaman bobot : Cara untuk kapsul yang berisi obat kering. Timbang 10 kapsul. Timbang lagi kapsul satupersatu. Keluarkan isi semua kapsul dan bobot rata-rata tiap isi kapsul. Perbedaan dalam persen bobot isi tiap kapsul terhadap bobot rata-rata tiap isi kapsul tidak boleh lebih dari yang ditetapkan kolom A dan untuk setiap 2 kapsul tidak lebih dari yang ditetapkan kolom B.

\begin{tabular}{lcc}
\hline \multirow{2}{*}{ Bobot rata-rata isi kapsul } & \multicolumn{2}{c}{ Perbedaan bobot isi kapsul (\%) } \\
\cline { 2 - 3 } & $\mathrm{A}$ & $\mathrm{B}$ \\
\hline 120 mg atau lebih & $\pm 10 \%$ & $\pm 20 \%$ \\
Lebih dari $120 \mathrm{mg}$ & $\pm 7.5 \%$ & $\pm 15 \%$ \\
\hline
\end{tabular}

Dari dua kali replikasi uji keseragaman bobot kapsul bawang putih yang diteliti diperoleh hasil bahwa kapsul yang dibuat telah memenuhi keseragaman bobot yang dipersyaratkan untuk sediaan kapsul. Dengan demikian bisa dinyatakan bahwa kapsul yang dibuat memiliki dosis yang seragam dan diasumsikan juga memiliki kendungan zat aktif dengan kadar yang seragam pula, sehingga diharapkan dapat menimbulkan efek terapi yang sama jika tiap kapsul tersebut dikonsumsi oleh pasien. 
Tabel 6. Uji keseragaman bobot kapsul bawang putih (Allium sativum Linn) 600 mg

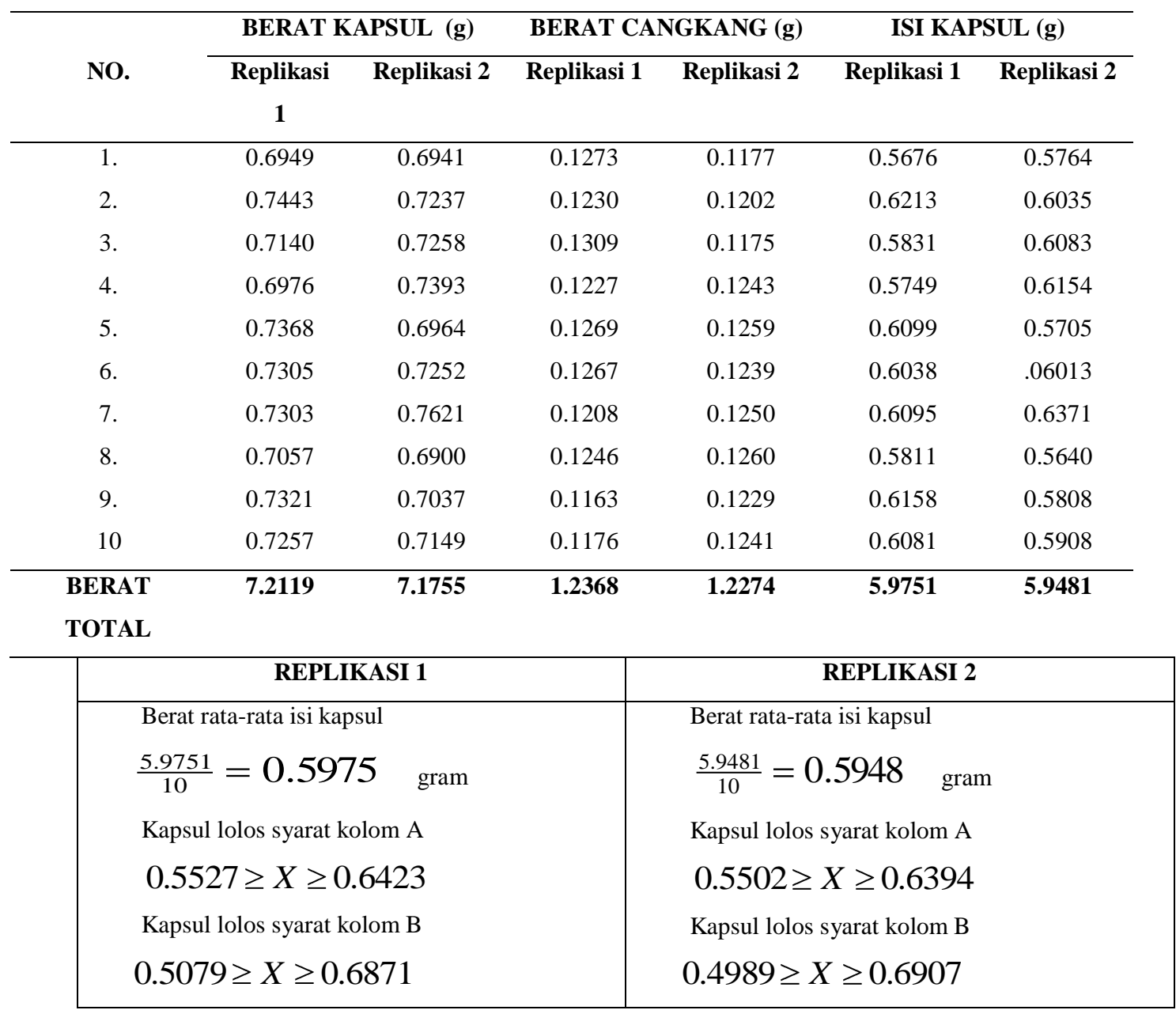

\section{Kesimpulan dan Saran}

\section{A. KESIMPULAN}

1. Ekstrak bawang putih dengan dosis 240 $\mu \mathrm{g} / \mathrm{ml}$ medium (setara dengan $600 \mathrm{mg}$ ekstrak bawang putih per kapsul) memiliki potensi paling besar.

2. Ekstrak kering bawang putih (Allium sativum Linn) memenuhi persyaratan sebagai bahan isi kapsul obat tradisional:

$>$ angka lempeng total ekstrak bawang putih 1.5, memenuhi persyaratan angka lempeng total isi kapsul obat tradisional tidak lebih dari 10

angka kapang dan khamir ekstrak bawang putih $6.10^{2}$, memenuhi persyaratan angka kapang dan khamir isi kapsul obat tradisional yakni tidak lebih dari $10^{4}$ bahan isi kapsul telah memenuhi persyaratan yaitu tidak mengandung mikroba patogen dalam isi kapsul obat tradisional (tidak terkontaminasi bakteri coliform, Eschericia coli, Salmonella sp, dan Staphylococcus aureus) pada bahan isi kapsul tidak terdeteksi adanya aflatoxin sehingga memenuhi persyaratan jumlah aflatoksin isi kapsul obat tradisional tidak lebih dari 30 bpj

kadar air rata-rata ektrak kering bawang putih (Allium sativum Linn) sebesar 1-2 \%, memenuhi persyaratan kadar air untuk isi kapsul obat tradisional tidak lebih dari $10 \%$

3. Kapsul ekstrak kering bawang putih (Allium sativum Linn) memenuhi persyaratan farmasetika untuk sediaan kapsul obat tradisional 
hasil uji waktu hancur kapsul bawang putih (Allium sativum Linn) $600 \mathrm{mg}$ adalah kurang lebih 13 menit, memenuhi persyaratan uji waktu hancur yakni tidak lebih dari 15 menit

$>$ bobot kapsul bawang putih yang diteliti memenuhi keseragaman bobot yang dipersyaratkan untuk sediaan kapsul

\section{B. SARAN}

1. Perlu dilakukan isolasi atau fraksinasi senyawa aktif yang terkandung dalam bawang putih yang paling berperan sebagai anti tubercolusis

2. Perlu dilanjutkan menuju uji klinis kapsul bawang putih $600 \mathrm{mg}$ sebagai anti TBC.

\section{Ucapan Terima Kasih}

Dinas Pendidikan dan Kebudayaan Propinsi Jawa Tengah yang telah mensupport penelitian bawang putih biasa sebagai terapi alternatif TBC.

\section{Daftar Pustaka}

Anonim, 1979, Farmakope Indonesia, Edisi III, 5-8, 807, 815, Departemen Kesehatan Republik Indonesia, Jakarta.

Anonim, 1993, Dasar-dasar Pemeriksaan Mikrobiologi, 27-29, Bagian Mikrobiologi, Fakultas Farmasi UGM, Yogyakarta.

Anonim, 1994, Persyaratan Obat Tradisional, Keputusan Menteri Kesehatan Republik. Indonesia No. 661/MENKES/SK/VII/19994, Departemen Kesehatan Republik Indonesia, Jakarta.

Anonim, 1997, Metode Analisis 91/92, $144-$ 145, 161-162, 163-164, 214-215,
Direktorat Jenderal Pengawasan Obat dan Makanan, Jakarta.

Anonim, 1998, Metode Analisis 97/98, 158160, 184-185, Direktorat Jenderal Pengawasan Obat dan Makanan, Jakarta.

Anonim, 2000, Standard Operating Prosedur (SOP) in Microbiology, 72-89, 140-147, Departemen Kesehatan Republik Indonesia, Jakarta.

Anonim, 2005, TBC (Tuberculosis), PUSTEKKOM, http://www.edukasi.net/pengpop/pp full.php?pp $\mathrm{id}=249 \&$ fname $=$ all.htm.

Anonim, 2007, Program Penanggulangan TBC, Pusat Kesehatan Kerja Departemen Kesehatan Republik Indonesia, http://www-20\%tbc\%20Departemen $\% 20$ Kesehatan, $\%$ In donesia.htm.

Hafid, A. F., dan Kusumawati, I., 2001, Penetapan Parameter Standar Ekstrak Etanol Temulawak Sebagai Bahan Baku Kapsul temulawak, Jurnal Penelitian Medika Eksakta, 2, 146-161.

Lay, B., W., 1994, Analisis Mikroba di Laboratorium, Edisi I, 10-15, PT. Raja Grafindo Persada, Jakarta.

Roser, D., 1991, Garlic for Health, diterjemahkan oleh Djaja Surja Atmadja, 66-67, PT. Bumi Aksara, Jakarta.

Syamsiah, I. S., dan Tajudin, 2003, Khasiat \& Manfaat Bawang Putih Raja Antibiotik Alami, Terbitan Keenam, 1-2,11-14, 28-59, AgroMedia Pustaka, Jakarta.

Thomas, A. N. S., 1989, Tanaman Obat Tradisional, 53, Kanisius, Yogyakarta.

Voigt, R., 1994, Lebrbuch Der Pharmazeutischen Technologie, 379, Gadjah Mada University Press, Yogyakarta 